\title{
FREUDIANA: AZ ÖRÖKSÉG TOVÁBB ÉL
}

\section{Szerzők:}

Simó Ferenc Zoltán (Dr. Jur.)

Debreceni Egyetem

\section{Lektorok:}

\author{
Mező Ferenc (PhD) \\ Eszterházy Károly Egyetem
}

Kelemen Lajos (PhD)

Okoskocka Kft.

Első szerző e-mail címe:

simofredz@gmail.com ...és további két anonim lektor

\section{Absztrakt:}

Ezen tanulmány egy trilógia második részének tekinthető, amely előkészít (terveink szerint) egy következő publikációt (angol nyelven), amelyben a „Freudiana” jelenlegi megítélését/tovább élését vizsgáljuk főként a 21. században, különös tekintettel a pszichológiai, nevelési és kulturális nézőpontokra. A „Freudiana” kifejezés Todd Dufresne-től (2003) származik, amelyet a szerző a freudi életmú egészére használ a Killing Freud címú művében. A Freud által képviselt látásmód és azzal együtt felbukkanó diszkurzus már a legelső pillanatoktól fogva megtalálta kővetőit és szélsőséges módon lojális híveit, de nyilvánvalóan nem maradt el az elméleteit ellenzők megjelenése sem. A vizsgálatunk tárgya a freudi örökség továbbélése különböző diskurzusokban.

Kulcsszavak: Freud, pszichoanalízis, személyiség, kultúra, populáris kultúra

Diszciplína: pszichológia, irodalomtudomány, kultúra tudomány

\section{Abstract}

\section{FREUDIANA: THE HERITAGE LIVES ON}

This study can be seen as the second part of the trilogy, paving the way to the last part of it in English, examining Freudiana, the Freudian Heritage, and its recent "life" in the 21 st century regarding psychological, educational and cultural points of views. The "coinage" Freudiana derives form Todd Dufresne (2003) used for the Freudian oeuvre in his work: Killing Freud. The theory of Freud and its discursive practice found his followers and his loyal subjects (even to the extremes) and, obviously, it was also 
rejected by many. In this study we intend to discuss how the Freudian discursive practice may survive concerning its relation to other disciplines as well.

Keywords: Freud, psychoanalysis, personality, culture, popular culture

Disciplines: psychology, literary studies, cultural science

Simó Ferenc Zoltán (2021). Freudiana: az örökség tovább él. OxIPO - interdiszciplináris tudományos folyóirat, 2021/2, 77-85. doi: 10.35405/OXIPO.2021.2.77

A pszichológia népszerūsége nem valószínű, hogy vitatható, tekintve azt a tényt, hogy számtalan pszichológia vagy magát annak tituláló művet találhatunk a könyvtárakban, könyvesboltokban, újságos standokon, de még a bevásárló központok polcain is. Tény az, hogy a pszichológia, mint független (és önálló) tudományos (vagy annak tekintett) diszciplínaként már a 19. században megjelent, anyaországának általában Németországot tekintjük. Akkoriban a pszichológia vizsgálatának legfőbb tárgya, és ezzel együtt a mozgatórugója, az úgynevezett „normális ember” (bármit is jelentett ez akkor és most) tudati világának vizsgálata és az ezen felfedezésekkel kapcsolatos elméletek és tételek (be)bizonyítása.A kor gondolkodásának megfelelően, a kor pszichológusai szerint a tudat szerkezeti elemei összefüggenek, szinte szorosan kapcsolódnak azokkal a folyamatokkal, amik az érzékszervekben zajlanak. Így, nem meglepő az sem, hogy a legfőbb feladatuknak a tudat alapelemeinek feltérképezését, illetve ezen elemek kapcsolati viszonyának meghatározását tekintették.
Nyilvánvaló, hogy ezt csak, mint fó csapásirányt nevezhetjük meg, hiszen léteztek olyanok is, ahogyan korunkban is, akik elképesztőnek tartották, sőt elutasították azt a lehetőséget, hogy a „lelket” tudományos módszerekkel kutassák. Ez a tábor még ma is képviselteti magát, bár indokolásuk a régebbi álláspontjuk szerintihez képes árnyaltabb és kifinomultabb. Szerintük, az elvetés korabeli igazolásához elég volt azt kimondani, hogy a „lélek” túl egyéni, szubjektív „valami” éppen ebből következik az, hogy a tudományos/objektív vizsgálata sem lehetséges. A behaviouristák például a pszichológiát egyes-egyedül a viselkedés tudományaként kívánták definiálni, és így kívánták „objektívebbé-mérhetőbbé” tenni magát a pszichológiát, mint tudományt. Ezzel szemben Freud $\mathrm{ma}$ is sokat idézett, használt, populáris megoldása, úgy szólt és ma is visszhangzik, hogy a ,lelket” jéghegyként kívánta értelmezni, amelynek a vízből kilátszó kisebbik része jelenti a tudatos tartományt, a nagyobbik rész, amely nem látható, az képviseli a tudattalant. 
A trilógia első részének a Freudiana-nak (Simó, 2020) a hagyományát követve, meg kell jegyeznünk, hogy e második tanulmány sem kíván egyik vagy másik tábor mellett állást foglalni, illetve egyik vagy másik szerző felett pálcát törni - ez legkevésbé sem a célunk. A cél nem más, mint belepillantani a freudi örökség továbbélésének elemeibe, vizsgálva azt, hogy vajon hol és hogyan is használták és használják fel a sokakban kettős érzéseket keltő elméletet.

Korunk feltételezhetően egyik bőszebb „Freud” kritikusa, Todd Dufresne, szerint két dolog miatt lehet még mindig Freud a leggyakrabban idézett szerzők egyike, de mindenképp vezető pozícióban van. Szerinte, első az a tény, hogy csak a „szokás hatalma" miatt idézik, tartalmi jelentősége nélkül (csak mert kell, mivel ő Freud). A második ok pedig, hogy a freudi alapokhoz köthető terápiás gyakorlat/kultúra mindenütt elterjedt az úgynevezett nyugati világban/kultúrában, és még mindig létezik az Egyesült Államokban, Kanadában, Angliában, Franciaországban és Argentínában (Dufresne, 2003). Bár a Dufresne által kifejtett (negatív) kritika jócskán nyilvánvaló, még ő sem merészkedik addig, hogy megkérdőjelezze azon a tényt, hogy Freud végérvényesen hatással volt a 20 és már a 21. századi intellektuális életre, és kultúrára egyaránt, illetve diskurzusának teremtő erejét sem kérdőjelezi meg egyértelműen.
Számos tudományág, mint például az irodalomtudomány, lelkesen használta fel Freud „eredményeit” és észrevételeit, bővítve ezzel azt a palettát, amely egyfajta gyakorlati felhasználásúvá tették, vagy inkább tehették a pszichoanalízist. Azonban Vajda Zsuzsanna szerint „(...) a magyar pszichoanalitikusok számos, a fejlődésre és az emberi természetre vonatkozó kérdésben Freudétól eltérő álláspontot képviseltek. A vélemény különbségek abból fakadtak, hogy budapesti hívei Freudnál konzekvensebben ragaszkodtak a Mester eredeti szándékaihoz: a természettudományos pszichológia megalkotásához. Bár mind a mai napig viták dúlnak a pszichoanalízis tudományelméleti meghatározásáról, és a leghevesebb bírálatok éppen a pozitív tudomány eszközeivel történő ellenőrzés lehetetlenségéhez kapcsolódtak, Freud számos sejtése, ötlete, elgondolása a fejlődéslélektan empirikus ágában is igazolásra talált” (Vajda, 1996, 329-330. o.). Ahogyan Vajda is megjegyzi, a fejlődéshez kapcsolódóan Freud-nál inkább beszélhetünk „sejtésekről”, „ötletekről” és „elgondolásokról”, mintsem kiforrott állításokról, bár azt is hozzá kell tennünk, hogy ez nem is képezte központi témáját Freud érdeklődésének. Érdekes azt is megfigyelnünk, hogy a Freud-ot övezô mítosz és tisztelet, a „Mester,” egy ilyen, 20 század végi tanulmányban is könnyen felfedezhető. Sőt a már-már elhíresült Jacques Derrida, francia filozófus (akinek nevét sokan a dekonstrukció fogalmával 
„azonosítják”) megjegyzi, hogy „bármely tudományágról legyen is szó, nem beszélhetünk úgy, nem lenne szabad, hogy úgy beszélhessünk, vagyis nincsen többé jogunk és lehetőségünk, hogy úgy akarjunk beszélni arról, mintha előzetesen valamilyen formában nyomot ne hagyott volna rajtunk a freudi impresszió." (Derrida, 2008, 35-36. o.).

Derridának mindig is merész kifejezései és csavaros értekezései voltak, de itt nem nehéz tetten érni, hogy ő is a mellett teszi le a voksát, hogy a freudi életmú, így vagy úgy nyomot fog hagyni minden (kapcsolható) tudományágban, illetve, hozzátehetjük, hogy a „nagy tudományokon” „kívüli” világot sem fogja érintetlenül hagyni. Félre ne értsük: itt Derrida nem a freudi elméletek működéséről vagy verifikációjáról akar meggyőzni minket, hanem inkább az elkerülhetetlen tényről, hogy a freudi diskurzus valamilyen formában hatással lesz ránk, akár tetszik, akár nem. Meg kell emellett jegyeznünk, hogy Dufresne nézete - miszerint Freud idézése a „szokás hatalma” - szemben áll például egy olyan radikális és jelentős gondolkodóval, mint Derrida.

Mindamellett, hogy Derrida befolyása is fellelhető, Borgos Anna (2017) egy más nézőpontból értékeli Freud hozzájárulását a kultúrához. A nemek kutatásához kapcsolódóan megjegyzi, hogy „Az utóbbi évtizedek a diskurzusok keveredését, időnként összecsapását mutatják - ez túlmutat a pszichoanalízisen, de hivatkozási pontként felismerhetők benne az elmélet egyes elemei” (Borgos, 2016, 34. o.). Nála is érezhetjük, hogy bár a freudi opus nem kifejezetten a központi helyen szerepel, de az irodalmi, társadalom- és kultúratudományokhoz kapcsolható vizsgálatok hivatkozási elemeként fellelhető. Ha pesszimistának akarnánk mutatkozni, ezt is értelmezhetnénk, a már többször emlegetett „szokásként”, vagy akár, bátran azt is állithatjuk, hogy Freud műveinek a felhasználhatósága úgy is túlélte a viharokat, hogy elméleteinek jelentős részét a szakma már elvetette, vagy (tudományos) bizonyosság hiányában erőskétkedéssel fogadja. Jelen mú számára elég, ha a freudi örökség jelenlétét és széles skálájú hatását fellelhetjük, hiszen nem tűztük ki célul, hogy egyik vagy másik elmélet vagy oldal mellett kiálljunk, pálcát törjünk (lásd még, például, Bánfalvi, 2001).

Innen már csak egy merész ugrás lenne azt állítanunk, hogy az az úgynevezett Freudiana tarolt a világ számos szegletében, tehát, nincs értelme elemezgetni, hogy miért és hogyan, de egy pillanatra fogadjuk el, hogy ez a tény. Attól tartunk, hogy ez semmiképpen sem lenne helytálló, hiszen van (nyílván) ellenpélda is. Adam Bzoch nem kis időt szentelt annak, hogy állításait alátámassza - szerinte: „A pszichoanalízis Szlovákiában nem létezett. Nem létezett önálló mozgalomként, nem voltak karizmatikus szereplői, akik a gyógyítás és az elmélet terén hozzájárultak volna a pszichoanalízis mint tudomány fejlődéséhez. Más nemzetektől eltérően 
sosem művelték intézményi keretek között, ahogyan az a kezdetektől fogva megszokott volt a nemzetközi pszichoanalitikus mozgalomban és az egyes nemzeti pszichoanalitikus társaságokban" (Bzoch, 2007, 9. o.).

Láthatjuk tehát, hogy nem „kötelező érvényűen" vált a freudi örökség használata egyfajta gyakorlattá, kellett hozzá egy „befogadó” réteg is (amely lehet akár ellenzők tábora is), hogy belefogjanak egy kapcsolható diskurzusba.

Bérdi Márk megközelítése is érdekes lehet számunkra, mivel megpróbálja öszszevetni Freud korabeli helyzetét az elméletei jelenlegi helyzetével. Megjegyzi, hogy „Freud mechanikus biológiai orientációja és a filozófia, irodalom iránti érdeklődése nem fonódhatott össze, addig ma már egyre több és komolyabb törekvés van arra, hogy a pszichoanalízis emberképét megpróbálják minél több ponton lehorgonyozni 'a tudományos emberképben” (Bárdi, 2011, 77. o.).

Érdekes számunkra itt is látni, hogy mennyire más környezetben született meg a freudi életmű, és milyen egyéb tényezők befolyásolhatták a más tudományokkal való összekapcsolását-összekapcsolódását. Azonban az úgynevezett ,tudományos emberképhez" való közeledésben azt a folyamatot is megpillanthatjuk, ahogyan Freud korában a pszichológia mint tudomány bontogatta szárnyait, illetve ezen törekvésnek a mai napig is tartó folyamatát vélhetjük felfedezni. Napjainkban sem látszik megtorpanni ez a folya- mat, hiszen több kutató is használja a freudi tanokat. Bucsics (2018) például (újra)értelmezi Kosztolányi és a freudizmus kapcsolatát, amely igen szoros, (lásd még: Pszichoanalízis a Literaturában: Thalassa, 2001/1. [Eredeti megjelenés:Literatura, 1931/5.]), azonban ő sem tartozik azok közé akik letennék a voksukat egyetlen értelmezésre. Véleménye szerint „Kosztolányi és a freudizmus viszonyának taglalása láthatóan több nehézséget is mutat, ennek belátásához elengedhetetlennek bizonyul az eddigi írások filológiailag kevéssé bizonyított, mégis magabiztos kijelentéseinek fölülvizsgálata. Azt az egész életmű vizsgálatára érvényes tanulságot nem lehet eléggé szem előtt tartani: bármiféle bizonyosság Kosztolányi egyegy témát, jelenséget illető vélekedéséről csakis erős megszorításokkal és körültekintéssel nyerhető ki az alkalmi nyilatkozatokból; a szépirodalmi szövegek részletei alapján való értelmezések pedig végképp nagy óvatosságot követelnek. Kosztolányi és a freudizmus viszonyának taglalása már évtizedekkel ezelőtt is a túlbeszéltség érzetét keltette, jóllehet nem egy kérdése máig is nyitott" (Bucsics, 2018, 23. o.). Bár ő is mélységes kétkedéssel fogadja a túl sok lehorgonyzott feszegetését a költő és a Freudizmus viszonyának, de azt sem tagadja, hogy több kérdés is nyitva marad. Értelmezésünk szerint ezt akár úgy is vélhetjük, hogy talán mégis lenne feszegetni való. Így úgy is olvashatjuk, hogy ezzel újabb tanulmányok megszületését is 
bátoríthatja ezen téma bizonyos részletei tekintetében, amely egyben a freudi örökség továbbélését biztosítja.

Freud elméleteinek és megállapításainak vizsgálatára vállalkozik Tánczos Péter is. $\mathrm{Az}$ ő értelmezésében „Freud univerzális jelentősége nem elméletének redukciós potenciáljában rejlik, hiszen a pszichoanalízis kiterjesztése nem vezet a szó pejoratív értelmében pszichologizáláshoz, hanem talán inkább abban található, hogy a pszichoanalízis módszere a megismerés és leírás általános igényével lép fel. Freud kiindulási pontja kétségtelenül az emberi psziché, ám ennek a lélektani koncepciónak mintha olyan strukturális mintázata lenne, amely alkalmas volna más diszciplínák modellezésére is" (Tánczos, 2012,1-2. o.). Ö is felismeri a helyzetben rejlő problemát - kijelenti, hogy: „A Freud által befolyásolt (esetleg átalakított) tudományok közül kitüntetett szerepével kiemelkedik a történelemtudomány, amely mintha különösen kedvező körülményeket biztosítana a pszichoanalízis gyakorlásához. Ez az adekváció persze nem jelent problémamentességet (...)" (Tánczos, 2012, 1-2. o.). Persze, hozzátehetjük, hogy a tudományos elméletek egymáshoz való közeledése vagy inkább közelítése is számos buktatót rejt(het) magába. Lásd például a freudi pszichoanalízis és irodalom kapcsolatát, amennyiben azt a tényt vesszük alapul, hogy a freudi elméletek jelentős részét már nem használjuk vagy nem értünk egyet velük.
Persze mégsem hagyhatjuk ki Freud egyik legismertebb kritikusát sem, aki nem más, mint Karl Popper, aki szerint ami „...Freudnak az énről, a felettes-énről és ösztön-énről szóló elbeszélését illeti, ez lényegében nem formálhat inkább jogot a tudomány státusára, mint a Homérosz által összegyüjtött történetek az Olümposzról. Ezek az elméletek leírnak bizonyos tényeket, ám a mítoszok módjára. A legérdekesebb pszichológiai sejtéseket foglalják magukba, de nem tesztelhetô formában" (Popper, 1993, 91-106. o.). Ugyanakkor még ő sem megy el addig, hogy kategorikusan elutasítaná az egyébként oly népszerü freudi elméleteknek, valamiféle „hasznát”: lévén, hogy azok még talán a „tudomány” számára is hasznosak lehetnek. Sőt vélhetjük úgy is, hogy tovább is viszi elmélkedését: „[f]elismertem ugyanakkor, hogy az ilyen mítoszokat tovább lehet fejleszteni, és tesztelhetővé válhatnak; valamint azt is láttam, hogy történeti szempontból minden - vagy majdnem minden - tudományos elmélet mítoszokból ered, és hogy egy mítosz tudományos elméletek fontos anticipációját tartalmazhatja" (Popper, 1993, 91 106. o.). Azonban így már kissé megenyhült változatot kapunk, ahol a „mítoszosan leírt tények és sejtések," mintha még fejlesztésre várnának, vagy magukban hordozzák azt a lehetőséget, hogy a freudi elméletek a gyermeki létükből, egyszer majd felnőtté vállnak, hogy ,anticipálhassanak” vagy elősegíthessenek ,tudományos elméleteket”. Számunkra itt is 
csak az a megjegyzendő, hogy a Freud elméleteit visszautasítok is láthatnak ,értékeket" bennük - ha csak annyit is, mint egy újkori drámának vagy érdekes történetek gyüjteményének tekintik is azt, ami a tudomány csiráit hordozhatja magába.

Figyelemreméltó lehet Szummer Csaba konklúziója is, aki szerint „bármennyire is csodálom azonban a mitikus narráció erejét, nem állítom, hogy Freud újítása csupán retorikai és narratív természetű volt, hogy a pszichoanalízis mítosz volna csupán. A pszichoanalízis amiatt válhatott a tudományelmélet egyik legnagyobb talányává, mert egy újszerű kommunikációs helyzetben empirikus ismereteket gyüjt, a megfigyelés sajátos, az empirikus és a hermeneutikai tudományok között álló átmeneti helyzetét alkalmazva, az élettörténet narratíváját újraalkotva. Másfelől azonban a pszichoanalízis számára a popperi vagy bármely más empirista tudományideál örökké elérhetetlen marad: az empirikus ,adatok” itt kibogozhatatlanul összefonódnak nem csupán az értelmezéssel, hanem a történetmondás múvészetével is. Megkockáztatom, a pszichoanalízis valódi jelentőségét valószínűleg nem a tudományos hozadéka adja, hanem mítoszra emlékeztető vonásai" (Szummer, 2005).

Nem szabad szem elől tévesz-tenünk, azt a tényt, hogy e tanulmány nem a freudi tanok valamely bírálata vagy pártolója mellé szeretne szegődni, hanem megkísérli bemutatni, hogy milyen módon formálja a Freudiana ('így vagy úgy) a tudományos gondolkodást, vagy inkább „együtt gondolkodást”, anélkül, hogy tetszene-e vagy sem maga az örökség egyegy vitatott vagy pártolt pontja.

A feltételezett ellentáborból, akik nem kifejezetten anti-freudi tanokat vallanak, érdemes megemlíteni Michael Rustint, aki kísérletet tesz arra, hogy a freudi tanok valahogy a tudományos beszéd tárgyai legyenek, melyek éppenséggel még erősíthetik is a pszichoanalízis 21. századi pozícióját. Továbbá munkássága arra utal, hogy nem hagyja veszni azokat a szociopolitikai jelentőségű pontokat ahol a pszichoanalízis, mint „tudás” releváns lehet - ezeket már az első cikkben is említettük (Simó, 2020). Ráadásul, ő az egyike azoknak, akik a brit pszichoanalitikus tradíció eredményeinek bemutatásával kívánják megteremteni a lehetôségét az újabb értelmezések megjelenésének. Ennek ékes bizonyítéka, például, a „Psychoanalysis and the Public Sphere: Social Fault Lines" nemzetközi online konferencia, melyet 2020. szeptember 1927. között tartottak meg (lásd: https://www.freud.org.uk/event/psycho analysis-and-the-public-sphere-socialfault-lines /)

Bár, némelyek még ezzel sem lennének, elégedettek, mondván, hogy ez sem elég a Freudiana továbbéléséhez, maximum, rövid vagy középtávon lehet segítség. Ezen kétkedők viszont nem számoltak azzal a ténnyel, hogy Iain MacRury és Michael Rustin nemcsak az úgynevezett 
„tudományos világ” felől „támad”, hanem a populáris kultúra talaján is jól mozognak. Vitatható lenne állításunk, ha nem egy olyan sorozat lenne a célpontjuk, amely a Guinness Rekordok Könyvében is, mint a világ leghosszabb ideig műsoron levő sci-fi sorozata szerepel, s amely szerves része brit popkultúrának is, de a világ szinte minden pontján ismert. Talán azért is, mert a „Ki vagy, doki?” (Eredeti cím: Doctor Who) 1963 óta van adásban. A BBC által készített brit televíziós sci-fi sorozat egy rejtélyes, földönkívüli idő-térutazó kalandjairól szól, aki magát a „Doktornak” nevezi és a TARDIS (Time And Relative Dimensions In Space) nevű időgépével utazik, és old meg különleges helyzeteket (MacRury, I and Rustin, M, 2014). Hatását tekintve az sem elhanyagolható, hogy ez a sorozat még mindig tart.

\section{Zárógondolatok}

A trilógia jelen, második részében sem kívánjuk vitatni, hogy az úgynevezett freudi „,tények” nagy többsége mára már nem állja meg a helyét, elutasításra vagy éppen kiigazításra számíthat a „tudományos" köröktől, melyek maguk is sejtik, hogy talán az ő elméletük sem az örökkévalóságnak készült. Azonban az antifreudisták is hozzájárulnak tagadásukkal vagy új, illetve módosított szemléletükkel/elméletükkel a Freudiana fennmaradásához, továbbéléséhez. Freud műveinek kulturális hozadéka, véleményünk szerint megkérdőjelezhetetlen, hiszen, ahogyan láttuk, nem egy kifejezett tudományterülethez kapcsolódóan van „jelen”, hanem áthallásokat, kötödéseket, kapcsolódási pontokat vélnek felfedezni a kutatók Freud múveit vizsgálva a mai napig. Ezen állítás továbbgondolása a trilógia harmadik részében, angol nyelven fog kiteljesedni.

\section{Irodalom}

Bánfalvi A. (2001): A pszichoanalízis mint álcás nő. Thalassa, 2-3, 55-82.

Bérdi M. (2011). Freud és a természettudományos pszichológia terveẓte. Imágó, Budapest. 77-92.

Borgos A. (2017): Pszichoanalitikus elméletek nőiességképe Freudtól a feminista pszichoanalízisig. In: Kovács M. (szerk.): Társadalmi nemek: Elméleti megközulitések és kutatási eredmények. ELTE Eötvös Kiadó, Budapest, 2137.

Bucsics K. (2018). Kosztolányi és a Freudizmus. Élő Irodalom. Somogy. 1. szám.

Bžoch A. (2007). Psychoanalýza na periférii. Kalligram, Bratislava. (Hungarian translation. Balogh Magdolna, 2016 and Hungarian edition, Typotex, Budapest, 2016)

Derrida, J. (2008). Az archívum kínzó vágya. Freudi impresszió. In: $A z$. archivum kinzó vágya: Archivumok morajlása. Kijárat Kiadó, Budapest 
Dufresne, T. (2003). Killing Freud: 20th Century Culture and the Death of Psychoanalysis. Continuum Books, London and New York

Freud, S. (1997). Pszichoanalizis. Kossuth Kiadó, Budapest

Freud, S. (1986). Bevezetés a pszichoanalízisbe. Gondolat, Budapest.

MacRury, I and Rustin, M. (2018). The inner world of Doctor Who psychoanalytic reflections in time and space. Routledge. New York.

Popper, K. (1993). A tudomány: feltevések és cáfolatok. In: Szummer CS. és Erős F. (szerk.): Filozófusok Freudról. Budapest, Cserépfalvi, 91106. 97.

Popper, K. (2002). Conjectures and Refutations: The Growth of Scientific Knowledge (Routledge Classics). Routledge, London. (Originally: Basic Books, 1962, New York)
Rustin, M. (2001). Reason and Unreason: Psychoanalysis, Science and Politics. Contionuum Books, London.

Simó F (2020). Freudiana. OxIPO interdiszciplináris tudományos folyóirat, 2020/4, 59-68. doi: 10.35405/OXIPO.2020.4.59

Szummer Cs. (2005). Freud avagy a modernitás mítosza. Beszélō Lapok. Évfolyam 10, Szám 12 (elérhetô: http://beszelo.c3.hu/cikkek/freudavagy-a-modernitas-mitosza)

Tánczos P. (2012). Freud és a történetírás squbverziv alakzatai - Nyelv és történetiség egy lehetséges együttgondolása posztstrukturalista perspektivából. Tanulmányok az emberi gondolkodás tárgykörében, ISBN 978-80-971251-9-6

Vajda Zs. (1996). A budapesti pszichoanalitikusok rendhagyó nézetei a gyermeki természetről és a nevelésről. Magyar Pedagógia 96 évf. 4. szám 329339. 